\title{
Historical analyses of debris flow disaster occurrences and of their scientific investigation in Brazil
}

\author{
DoSSIER DAS ÁGUAS : GESTÃo Do PATRIMÔNIO HÍDRICO
}

\section{Masato Kobiyama}

Professor. Institute of Hydraulic Research , Federal University of Rio Grande do Sul. Porto Alegre [RS] Brazil. $<$ masato.kobiyama@ufrgs.br>.

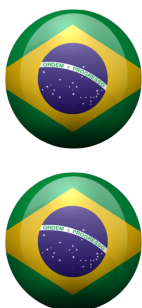

\section{Gean Paulo Michel}

Sanitary and environmental engineer. PhD student of Water Resources and Environmental Sanitation. Institute of Hydraulic Research, Federal University of Rio Grande do Sul. Porto Alegre [RS] Brazil. <gean.michel@ufrgs.br>.

\section{Elisiele Cardozo Engster}

Undergraduate student of Geography. Institute of Hydraulic Research, Federal University of Rio Grande do Sul. Porto Alegre [RS] Brazil. <elisiele.engster@ufrgs.br>.

\section{Maurício Andrades Paixão}

Undergraduate student of Environmental Engineering. Institute of Hydraulic Research, Federal University of Rio Grande do Sul. Porto Alegre [RS] Brazil. <paixaomauricio@uol.com.br>.

\begin{abstract}
Considering the debris flow as highly-destructive flow of water and sediment mixture in a way where it is a gravity-governed continuous flow, the present paper conducted a Web survey of technical-scientific studies that treated these phenomena which occurred in Brazil during the period 1900-2014. Although the increase of occurrence from the 1990s caused the increase in the number of publication, there are still a small number of publications, especially in scientific journals. A historical analysis about Brazilian studies demonstrates an actual situation in Brazil and confirms various necessary and urgent actions. Among them, the more important actions are: (1) establishment of terminology and concept about debris flow in Brazil; (2) systematization of hydrometeorological monitoring and topographic survey; (3) registration of occurrences and data-base construction; and (4) development of woody debris flow researches.
\end{abstract}

\section{Keywords}

Debris flow, scientific researches, history. 


\section{Introduction}

Debris flows have been increasingly causing serious damages to the human society and the environment in the world including Brazil. This fact indicates the importance of developing more scientific researches to understand the mechanisms of such natural phenomena and the countermeasures required to reduce related disasters. In these circumstances, the International Conference on Debris-Flow Hazards Mitigation: Mechanics, Prediction and Assessment was held in San Francisco (USA) in 1997, Taipei (Taiwan) in 2000, Davos (Switzerland) in 2003, Chengdu (China) in 2007, Padova (Italy) in 2011, and Tsukuba (Japan) in 2015. A similar event called International Conference on Monitoring, Simulation, Prevention and Remediation of Dense and Debris Flow was conducted four times: in Rhodes (Greece) in 2006, New Forest (England) in 2008, Milano (Italy) in 2010 and Dubrovnik (Croatia) in 2012.

Previously, scientists who devoted themselves to the study of debris flows had no opportunity to see this alive and real phenomenon directly. Thus the information was drawn through testimony from a few witnesses and observations of the deposition area of the debris flow after it occurs. It means that, in fact, scientists could just imagine how the flow developed. Okuda et al. (1977) showed for the first time the world a film of a debris flow, which significantly facilitated the understanding of its mechanisms. In this sense, the contribution of Okuda's work and his group was de extreme importance.

The work entitled "Debris flows" of Takahashi (1991), published in the series of monographs of the International Association of Hydraulic Engineering and Research - IAHR, was the first book written in the world that exclusively addressed this phenomenon systematically and was a major stimulus to scientific community. Today there are many books dealing only with this phenomenon (e.g., MICHIUE \& ARMANINI, 1997; JACOB \& HUNGR, 2005; TAKAHASHI, 2007), as well as review articles (INNES, 1983; DAVIES et al., 1992; HUTTER et al., 1996; COUSSOT \& MEUNIER, 1996; IVERSON, 1997; IVERSON et al., 1997; HUNGR et al., 2001; VANDINE \& BOVIS, 2002; TAKAHASHI, 2009).

Analyzing disasters related to landslides, Petley (2012) and Sepúlveda \& Petley (2015) showed a trend where countries with a large number of scientific papers treating landslides suffer less from these disasters. It implies that Brazilian society also needs to go further in their studies about debris flows in order to reduce the disasters caused by them.

Therefore, the objective of the present study was to investigate the concept of debris flow and to perform a historical and quantitative research on technical and scientific papers dealing with this phenomenon in Brazil. According to Alexander (1989), the debris flow is the most destructive type among all the types of mass movements, and is responsible for more deaths in the urban area. This comment is probably still true in Brazil and in the world.

\section{Terminology and concepts}

Takahashi (2007) defined the debris flow as "a flow of sediment and water mixture in a manner as if it was a flow of continuous fluid driven by gravity", and commented that such a phenomenon has great mobility. According Iverson (2004), the debris flow is a transitional phenomenon of mass movement whose characteristics were alternated between slipping and flooding. Coussot \& Meunier (1996) considered that the debris flow is an intermediate phenomenon among hyperconcentrated flow and landslide. Precisely because of its transitional or intermediate characteristics, there are various definitions and consequently inaccuracies.

Owing to the flow and transition nature, several studies have sought to differentiate between debris flows and other similar ones. For example, Costa (1988) attempted to differentiate debris flows, hyper-concentrated flows and floods. Imaizumi et al. (2008) differentiated landslide and debris flow. Of any form, there are several attempts to establish concepts related to this phenomenon. Table 1 shows some examples. 
Table 1. Different concepts to define the debris flows.

\begin{tabular}{|l|l|}
\hline Authors & Concepts \\
\hline Varnes (1978) & $\begin{array}{l}\text { Flow is the rapid movement of viscous material. There are debris flow, mud flow and rocks } \\
\text { avalanche, depending upon the nature of the material involved in the movement. } \\
\text { The debris flow is a visco-plastic, non-Newtonian fluid or dilatant fluid in laminar manner, } \\
\text { with uniform profile of sediment concentration. The sediment concentration varies from 70 } \\
\text { to 90\% by weight (47 to 77\% by volume). The shear stress is greater than } 400 \text { dyn/cm². }\end{array}$ \\
\hline Jan \& Shen (1997) & $\begin{array}{l}\text { Debris flows is a gravity flow of material composing a mixture of soil, rock, water and/or } \\
\text { air, coming from landslide with large amount of runoff. Their properties vary according to } \\
\text { the amount of water and clay, the sediment size and its distribution. }\end{array}$ \\
\hline USGS (1997) & $\begin{array}{l}\text { Debris flows are fast-moving landslides which occur in various parts of the world. They are } \\
\text { particularly dangerous to life and property, because they abruptly move and destroy } \\
\text { objects on their path, and often occur without warning. }\end{array}$ \\
Vandine \& Bovis (2002) & $\begin{array}{l}\text { The debris flow is a type of mass movement, which involves the rapid movement of } \\
\text { organic and inorganic materials (predominantly coarse material), saturated with water } \\
\text { and along confined and sloping channel. }\end{array}$ \\
\hline Imaizumi et al. (2008) & $\begin{array}{l}\text { Mass movements are divided into two types: slopes and channels. The movements of } \\
\text { slopes and channels are considered landslides and debris flows, respectively. }\end{array}$ \\
\hline IRDR (2014) & $\begin{array}{l}\text { The debris flow is a type of slip that occurs when heavy rain causes the descent of a large } \\
\text { amount of debris (woods, rocks, mud, etc.) on slopes by the action of gravitational force. }\end{array}$ \\
\hline $\begin{array}{l}\text { The debris flow is a very dangerous phenomenon in mountainous regions. This } \\
\text { phenomenon is different from the other types of landslides because of the fact of periodic } \\
\text { occurrences though the established trajectories which are normally gully and first or } \\
\text { second-order basins. }\end{array}$ \\
\hline Hungr et al 2014)
\end{tabular}

The debris flow is very common in mountains. Consequently there are several words to call it. In Japan, people call it ja-nuke which is an image of large snake destructing valley, doseki-ryu meaning soil-rock flow, yama-tsunami meaning mountainous tsunami, and so on. In Brazil, the terms corresponding to debris flow are diverse, consisting of a combination of terms which replace the word flow (fluxo/corrida/movimento/torrente) and the word debris (detritos/escombros/massa), i.e., fluxo de detrito, fluxo de escombros, corrida de massa, among others. Thus even in one country there are diverse terminologies.

Indeed, it is necessary to discuss the characteristics of the flowing material, i.e., debris. Hungr et al. (2001) defined debris as loose and non-uniform material with low plasticity. Texturally, the debris is a mixture of sand, pebbles, boulders and silt. Frequently, the debris can contain organic materials such as trunks, branches, among others. According to Cruden \& Varnes (1996), there are two types of materials that constitute flows: debris and land. The debris is soil containing stones and other coarse particle sizes in a higher proportion than $20 \%$, while the lands would consist of this proportion less than $20 \%$.

As debris flow is a phenomenon causing disasters, it can be handled from the point of view of natural disasters and protection/civil defense. In 2008, the Emergency Disaster Data Base (EM-DAT) of the Centre for Research on the Epidemiology of Disasters (CRED) which is the partner agency of the World Health Organization reclassified the disasters types into two major groups: natural and technological (SCHEUREN et al., 2008). Natural disasters were divided into six sub-groups: biological, geophysical, climatological, hydrological, meteorological and extraterrestrial (meteorites), and these, in turn, into twelve subtypes. This new classification was the result of an initiative between the two main disaster databases, the CRED and the Munich Reinsurance Company (MunichRe), which decided to adopt a common classification for their respective databases (BELOW et al., 2009).

The main change was the separation of the mass movements into two types: dry and wet. The first is associated only to geophysical events (earthquakes and eruptions) and the second to hydrological 
conditions (rainfall and water-table). Regardless of origin, such mass movements are commonly called landslides. The UN-International Strategy for Disaster Reduction (UNISDR) also adopted the new classification, since the EM-DAT is the primary database used by the UN, as noted in UNDP (2004). Moreover, a subsequent updating of the classification used by CRED was performed, which use no longer the disaster extraterrestrial (GUHA-SAPIR et al., 2012). Thus, Table 2 shows the summary of former and current natural disasters' classifications established by the CRED and the UN. In this classification, the debris flow is a part of the (wet) mass movements, which indicates that the debris flow is considered one type of hydrological disasters by UN.

Table 2. Former and current ratings of natural disasters in CRED - UN.

\begin{tabular}{|l|l|l|}
\hline Former classification & Current classification & Main types \\
\hline Geological & Geophysical & Earthquakes, volcanoes, mass movements (dry) \\
\hline \multirow{2}{*}{ Hydrometeorological } & Meteorological & Storms \\
\cline { 2 - 3 } & Hydrological & Floods, mass movements (wet) \\
\cline { 2 - 3 } & Climatological & Extreme temperatures, droughts, fires \\
\hline Biological & Biological & Epidemics, pests, insect infestations \\
\hline
\end{tabular}

Recently, Brazil (2012) launched the Law 12608/12 establishing the National Policy of Protection and Civil Defense (PNPDEC). As a result of Brazilian history, due to a lot of losses associated with natural disasters, the PNPDEC shows several aspects, quotes, and intentions that relate to water resources and their management. As Venderuscolo \& Kobiyama (2007) pointed out, the interfaces between the PNPDEC and the National Policy of Water Resources (PNRH) which was established by Law No. 9433/97 (BRAZIL, 1997) should be analyzed in more detail.

For a better explanation of some aspects of PNPDEC, Ministry of National Integration (2012) published the Normative Instruction No. 01. In this Instruction, there are several fragments of the text where the federal government expresses the way to conduct the Brazilian classification of natural disasters:

\begin{abstract}
"Art. 7o The Protection and Civil Defense Secretary will adopt the EM-DAT/CRED classification of disasters and correspondent symbology".

"Art. 8 For attending the classification of EM-DAT the Protection and Civil Defense Secretary starts to adopt the Brazilian Classification and Coding of Disasters - COBRADE, as shown on Attachment I of this Normative Instruction.

"ATTACHMENT I - BRAZILIAN CLASSIFICATION AND CODING OF DISASTERS (COBRADE)

[...] To suit the Brazilian classification to the classification used by the United Nations represents the follow up of international developments in classification of disasters and represents the leveling of Brazil to the other disaster management agencies all around the world. Furthermore the classification adopted by the United Nations is simpler than Disasters Coding (CODAR) currently used by SINDEC".
\end{abstract}

From the three expressions mentioned above, it is clear that the federal government intended to make the Brazilian classification and coding (COBRADE) very similar to the international classification used by the UN, although the Brazilian classification is more detailed. However, it can be clearly observed that the COBRADE does not follow the change of classification performed by CRED, and almost maintains the old style classification (Table 3).

As mentioned above, in the international classification, the debris flow corresponds to a type of landslides that falls into the category of wet mass movements, which in turn belongs to the hydrological disaster class. On the other hand, in the Brazilian Classification and Coding of Disaster (COBRADE), it belongs to the category of geological disasters that includes the mass movements that, in turn, encompass landslides, debris flows, and so on. These debris flows are divided into two types: soil/mud 
and rock/debris whose codes are 1.1.3.3.1 and 1.1.3.3.2 in COBRADE, respectively. Thus, it can be said that the Brazilian classification does not match the international classification in relation to debris flows. Since this phenomenon is a kind of wet mass movement, debris flows should be classified as hydrological disasters by respecting the Art. 7 of PNPDEC. Here it is worth remembering that Kobiyama et al. (2010a) showed that among all types of natural disasters, hydrological disasters (floods + landslides) are those lead to the major problems in Brazil and in the world.

Table 3. Comparison between Brazilian and international classifications of natural disasters.

\begin{tabular}{|c|c|c|c|}
\hline \multicolumn{2}{|c|}{ Brazilian Classification (COBRADE) } & \multicolumn{2}{|c|}{ International Classification } \\
\hline Class & Example & Class & Example \\
\hline Geological & $\begin{array}{l}\text { - Earthquakes } \\
\text { - Volcanism } \\
\text { - Mass Movements } \\
\text { - Erosion }\end{array}$ & Geophysical & $\begin{array}{ll}\text { - } & \text { Earthquake } \\
\text { - } & \text { Volcanism } \\
\text { - } & \text { Mass Movements (dry) }\end{array}$ \\
\hline Meteorological & $\begin{array}{l}\text { - Large-scale systems } \\
\text { - Storms } \\
\text { - Extreme temperatures }\end{array}$ & Meteorological & - Storms \\
\hline Hydrological & $\begin{array}{ll}\text { - } & \text { Floods } \\
\text { - } & \text { Flash floods } \\
\text { - } & \text { Waterloggings }\end{array}$ & Hydrological & $\begin{array}{ll}\text { - } & \text { Floods } \\
\text { - } & \text { Mass movements (wet) }\end{array}$ \\
\hline Climatological & - Drought & Climatological & $\begin{array}{l}\text { - Extreme temperatures } \\
\text { - Dry / drought } \\
\text { - Fires }\end{array}$ \\
\hline Biologic & $\begin{array}{l}\text { - } \text { Epidemics } \\
\text { - Infestations / pests }\end{array}$ & Biologic & $\begin{array}{ll}\text { - } & \text { Epidemics } \\
\text { - } & \text { Insect infestations } \\
\text { - } & \text { Stampedes of animals }\end{array}$ \\
\hline
\end{tabular}

Regarding to the phenomenon itself, to the type of flowing material, to the disaster category associated with this phenomenon, among others, there is a wide variety of terms and concepts. Brunsden (1979) commented that the terminology and classification of debris flows are not satisfactory. A literature review conducted by the present study shows that this problem still remains in the scientific community. Adding to the complexity and difficulty in identifying the phenomena, the absence of administrative agreement makes the investigation survey in a literature more costly and complicated.

Based on all the above examples, the present study uses the technical term "debris flow" and defines it as a flowing phenomenon that occurs from the landslide initiation. Due to the fluidity of the mixture, its runout is often very long. However, the present study does not discuss in detail this value.

\section{Materials and methods}

Considering the diversity of Portuguese terms (fluxo de detritos, fluxos de escombros, corridas de massa, escorregamentos, deslizamento, etc.), the present study searched the databases available on the Internet and in libraries, undergraduate's monographs, master's theses, and doctor's dissertations produced in Brazilian universities. By trying to collect the largest possible number of papers dealing with debris flows in Portuguese and English, papers published in scientific meetings and journals as well as international and national books in the field of geosciences and engineering were sought.

The information contained in each paper (for example, the phenomenon description and photos) was also used to judge whether the working topic was really related to debris flow. For example, 
if one paper addressed only translational landslides, it was not considered as a publication related to debris flows, and was excluded from the final analysis in the present study.

\section{Results and discussion}

\subsection{Old record}

Schlumberger (1882, cited TAKAHASHI, 1983) wrote one of the first reports about debris flows in the world literature. Seeking for the old Brazilian literature, an account of the priest Anchieta describing his experience in Piratininga, São Paulo state, in 1560 was found (CORRÊA FILHO, 1954):

[...] It fell so violently that seemed to threaten us with the Lord destruction; shook the house, snatched the roofs and overthrew the woods; the colossal tall trees ripped up by the roots, broke into other smaller pieces, smashed other, so that the roads were blocked, and there was no passage through the woods, it was to wonder how many damage trees and houses produced in half an hour. [...] (CORRÊA FILHO, 1954).

It is noted that this report probably describes the occurrence of an extremely-intensive rainfall event and a series of debris flows (or mud flow). Therefore, this can be considered the oldest record related to this phenomenon in Brazil. After him, several people recorded debris flows in more or less scientific ways.

\subsection{Historical analysis}

In the survey conducted by searching the Internet and in libraries, 162 works published during the period 1949-2014 were totally found. The detail description of all the publications is in Kobiyama \& Michel (2015). Although the researched period extends from the beginning of the twentieth century, no technical-scientific report was elaborated by 1949. It was noted that many Brazilian works, directly or indirectly, adopted a classification of Varnes (1978). Figure 1 shows the number of works divided into four categories: books; papers in journals; papers in proceedings; and monographs (theses, dissertations and technical reports). Most of publications are papers in proceedings, which implies a limited quality of scientific production related to this phenomenon in Brazil. The small number of scientific books has caused the difficulty inherent to the study of this phenomenon.

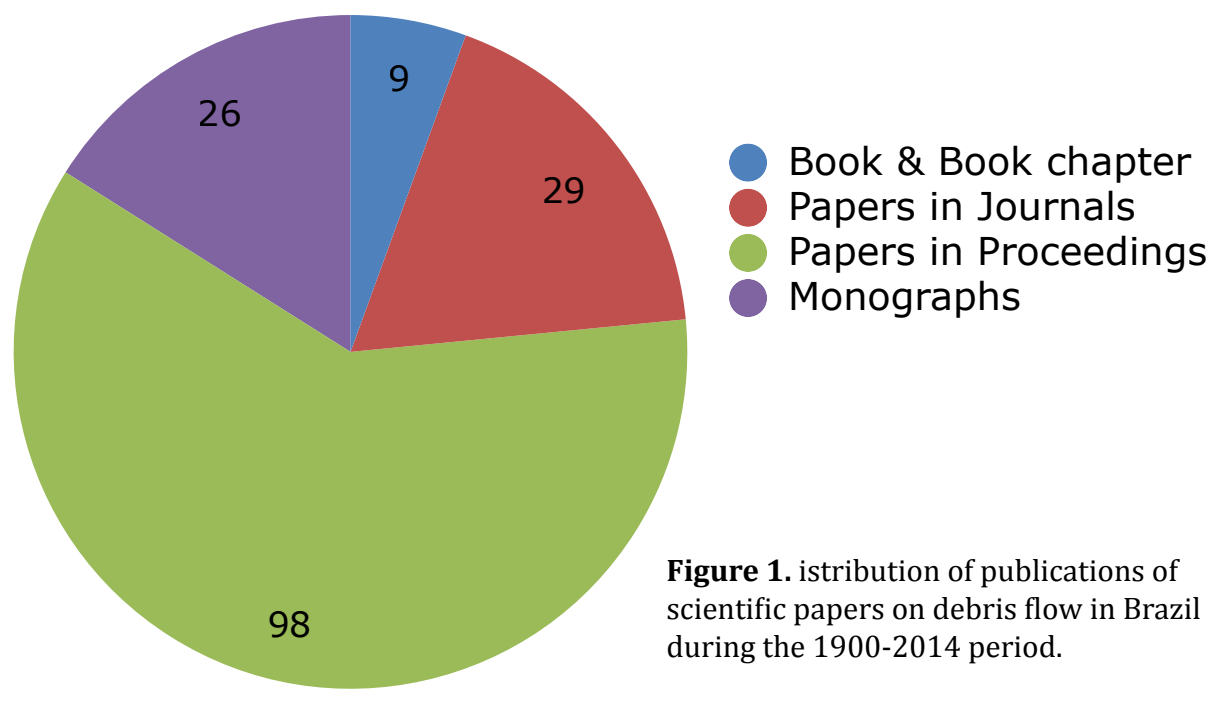

Figure 2 shows the historical trend of scientific studies during the period from 1900 to 2014 . Although various publications have been made in the period 1966-1975, in the 1990s a significant increase in publications began. 


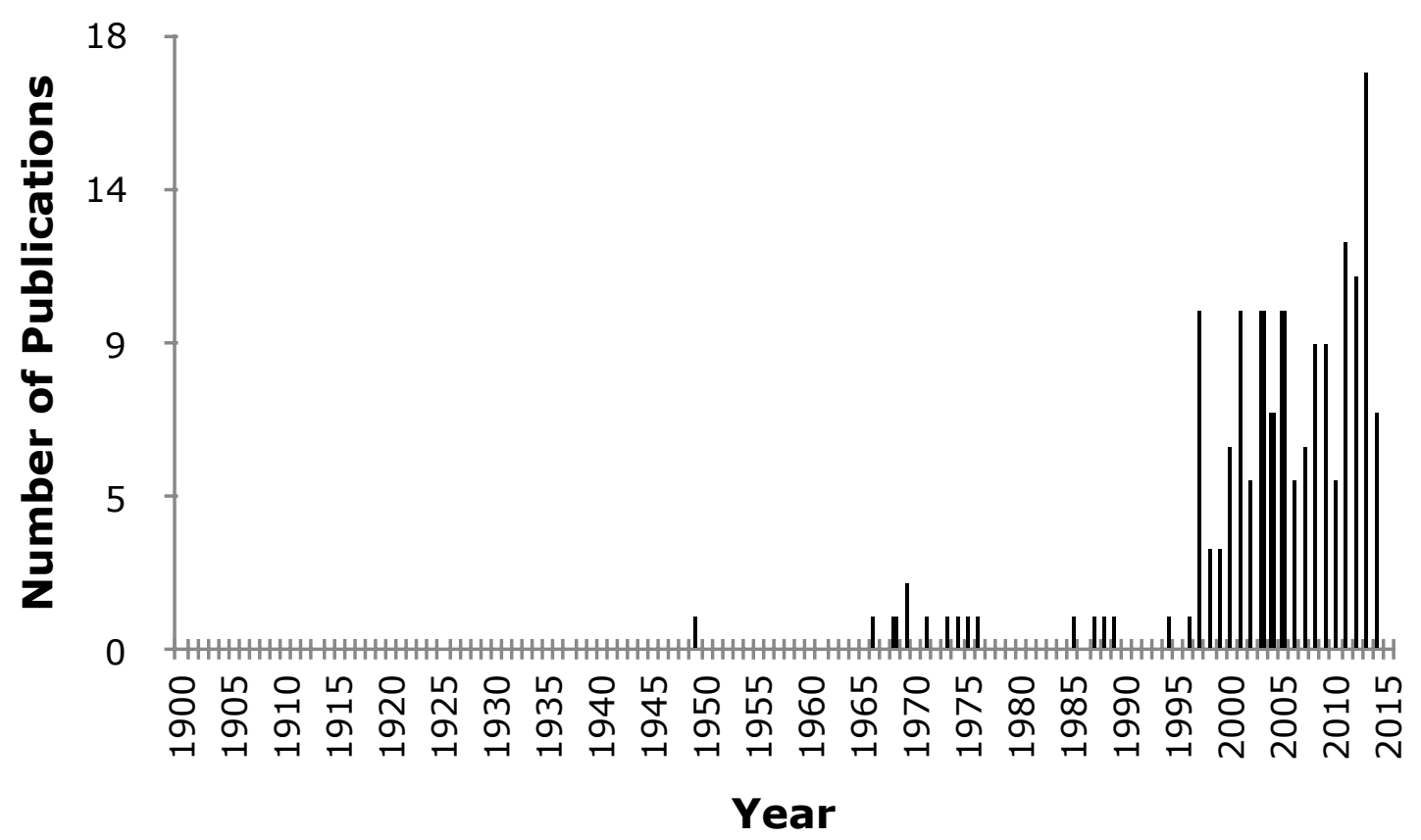

Figure 2. The scientific work history on debris flows in Brazil in the 1900-2014 period.

Analyzing Marcelino et al. (2006) and Tominaga et al. (2009), among others, the present study sought information on occurrences of debris flows in Brazil during the period 1900-2014. It can be said that the oldest disaster caused by debris flow in Brazil, technically registered, took place in Santos in 1928, causing 80 deaths and partial destruction of the Santa Casa hospital. Nevertheless, the scientific community did not investigate this disaster. Table 4 shows that during the period 1966-1975 disasters related to large debris flow occurred. In addition, from the 1990s, debris flows that caused large numbers of fatalities occurred more often. A comparison of Figure 2 with Table 4 confirms that the number of publications has been elevated with the increase of the occurrence of debris flows.

Table 4. Disaster with debris flows in Brazil (1900-2014).

\begin{tabular}{|r|l|r|}
\hline Year & \multicolumn{1}{|c|}{ Location } & $\begin{array}{c}\text { Number of deaths } \\
\text { (approximate) }\end{array}$ \\
\hline 1928 & Santos (SP) & 80 \\
\hline 1948 & Vale do Paraíba (SP/RJ) & 250 \\
\hline 1956 & Santos (SP) & 64 \\
\hline 1966 & Rio de Janeiro (RJ) & 100 \\
\hline 1967 & Serra das Araras (RJ) & 1700 \\
\hline 1967 & Caraguatatuba (SP) & 120 \\
\hline 1971 & Salvador (BA) & 104 \\
\hline 1972 & Campos do Jordão (SP) & 10 \\
\hline 1974 & Tubarão (SC) & 40 \\
\hline 1986 & Lavrinhas (SP) & 11 \\
\hline 1988 & Cubatão (SP) & 10 \\
\hline 1988 & Petrópolis (RJ) & 30 \\
\hline 1988 & Rio de Janeiro (RJ) & 171 \\
\hline & & \\
\hline
\end{tabular}




\begin{tabular}{|r|l|r|}
\hline 1989 & Salvador (BA) & 100 \\
\hline 1990 & Blumenau (SC) & 14 \\
\hline 1992 & Contagem (MG) & 36 \\
\hline 1995 & Timbé do Sul (SC) & 29 \\
\hline 2001 & Petrópolis (RJ) & 51 \\
\hline 2008 & Vale do Itajaí (SC) & 135 \\
\hline 2010 & Angula dos Reis (RJ) & 30 \\
\hline 2011 & Serra Fluminense (RJ) & 978 \\
\hline 2013 & Petrópolis (RJ) & 33 \\
\hline
\end{tabular}

Modification from Marcelino (2003) and Rosa Filho \& Cortez (2008).

\subsection{Suggestions for necessary actions in Brazil}

The historical analysis of studies on debris flows in Brazil demonstrates the current situation and brings several actions that should be urgently implemented. Based on the fact that studies on debris flows may be relevant in understanding the mechanism of sediment production and management of debris-flow disasters, the present study suggests (1) establishment of standard concept and terminology; (2) systematization of hydro-meteorological monitoring and topography surveying; (3) registration of the occurrences and database construction; and (4) development of research on woody debris flows.

\subsubsection{Establishment of standard concept and terminology}

As above mentioned, people in Brazil use the various terms for debris flows, for examples, fluxo de detrito, fluxo de escombros, corrida de massa, and so on. Though the Protection and Civil Defense in Brazil uses the term corrida de massa in the COBRADE, this term does not seem popular in the scientific community. Furthermore, in terms of disaster, this phenomenon is classified as hydrological by CRED (international) and as geological by COBRADE (national level). Thus, exists a divergence in terminology and concept related to this phenomenon.

Since debris flows have a transitional and fluidity characteristics, subjectivity lies on its definition, identification and description even in the scientific community. To reduce the subjectivity in the identification of these phenomena, some criterions could be used. For example, Wilford et al. (2004) considered the debris flow, debris flood and flood as hydrogeomorphic processes and proposed a quantitative method to differentiate them by morphometry. This type of quantitative methodology should be increasingly sought and used in Brazil in order to improve the registration methodology. Since the environment in Brazil is characterized with high temperature, rainfall and biodiversity, debris flows in Brazil may differ from those outside of Brazil, especially in Europe and North America. The Brazilian scientific community should, hence, discuss more to establish the standard terminology and concept.

\subsubsection{Systematization of hydro-meteorological monitoring and topography surveying}

It is commonly said that heavy rainfalls can cause debris flows (ZNAMENSKY, 2014). Therefore, the rainfall necessary to trigger debris flows (for example, SUZUKI et al., 1979; SUZUKI \& KOBASHI, 1981; SUZUKI \& KOBASHI, 1987; GLADE \& WIECZOREK, 2005) and landslides (e.g., TATIZANA et al., 1987; MICHEL et al., 2015) is one of the main issues currently addressed in science and technology dedicated to disaster management. Debris flows almost always occur with heavy rainfalls. Due to this fact, the CRED revised its classification of natural disasters, inserting debris flows in the category of hydrological disasters. So hydrological monitoring, especially of rain, should be even more intensified in Brazil. 
To advance further, it is necessary to implement an automatic monitoring system of rainfall and discharge. Since debris flows are phenomena that occur abruptly, especially in mountainous regions, this system should be implemented more intensively in the headwaters regions and preferably should have high temporal intensive data collection (measurement intervals equal to 10 minutes or shorter).

The sediment production associated with a debris flow event is typically high, which can clearly be observed in the field. However, recognition of a more quantitative perspective of events is still far from satisfactory condition. It is due to the lack of topographical information before and after the event. Then, the steeper regions which exhibit a greater tendency to the occurrence of debris flows should be topographically described with greater precision and frequency. In addition, conducting surveys in the initiation zones, transport and deposition of newly occurring debris flows can provide important information in advance of studies that address the phenomenon.

\subsubsection{Registration of the occurrences and database construction}

A science or a scientific study of one phenomenon almost always starts from its observations. Therefore, to advance the science of debris flows, the record of all the instances, regardless of the event that have caused a disaster, is fundamental. There are several equations established only from databases which contained occurrences records, for example, the equation that relates the runout angle to the total volume of produced sediments (COROMINAS, 1996; RICKENMANN, 1999). Since an equation that describes the Brazilian situation had not yet been elaborated, Kobiyama et al. (2010b) compared their results with phenomena that occurred in Europe, using one figure of Rickenmann (2005). To verify the similarity between Brazilian and European situations and to generate its own equation describing Brazilian debris flows, it is imperative that a database containing debris flow occurrences records is created and fully available to all interested sectors.

In the preparation of records and database construction, it is necessary that certain minimum standards are highlighted. There are, in general, suggestions and manuals for landslides records, for example, handbook or guidance of Highland \& Bobrowsky (2008) and Corominas et al. (2014). However, a detailed manual to record the occurrence of debris flow has not elaborated yet. Rainfall regime, topographic information and occurrence time are the fundamental characteristics to be recorded. Furthermore, if possible, pedological, geological, sedimentological, rheological, hydraulic, and other hydrological characteristics should be also registered.

\subsubsection{Development of research on woody debris flows}

Normally, debris flows have a mixture of two phases (water and sediment). In the case of a mountainous region covered by forest, the trunks represent their significant presence. However, the effects of trunks (or vegetation in general) on the occurrence mechanisms of debris flows are not recognized scientifically in a satisfactory way (LANCASTER et al. 2003; STOFFEL \& WILFORD, 2013). Although there are several attempts to model the woody dynamics in the flows (WALLERSTEIN, 2003; MAZZORANA et al., 2011; SHRESTHA et al., 2012), no model is still capable to do it very satisfactorily.

For the temperate climate condition, Seo et al. (2010) conducted a literature review on the dynamics of the logs at the river basin level. Their description was just qualitative. In Brazil the tropical and subtropical climates facilitate the increase both in the biodiversity and in the biomass in the basins, especially in riparian zones. Since the riparian vegetation is very rich, the presence of vegetation and logs can be exceptionally significant for the debris flow occurrences. It means that, when a debris flow occurs in Brazil, it can be categorized as a woody debris flow. Thus, studies in Brazil should focus on the dynamics of the logs in the full context of debris flow.

\section{Final considerations}

Debris flows do not occur frequently in Brazil. However, when they occur, they are capable to cause large losses and fatalities. In order to reduce disasters associated with debris flows, several measures 
are required. Among them, the registration and description of such phenomenon at the moment of their occurrence as well as education/training prior to its occurrence should be emphasized. To promote education related to debris flows, teaching materials which in turn depend on the existence of records are indispensable. Because such phenomena usually occur in mountainous regions, ordinary citizens need to receive a good education on this topic for registering them more appropriate and detail. Goerl et al. (2012) reported that the debris flow may be one of the main objects of hydrogeomorphic study. Hence, this science should be more widespread at all levels of education in Brazil and should advance the understanding of this phenomenon.

Due to the high speed and huge extension, the debris flow is considered an important geomorphic agent. Its occurrence can be a source of large amounts of sediment to the river network (GABET \& DUNNE, 2003). According Benda et al. (2003), the debris flow changes the fluvial morphology and affects aquatic ecology. Along the large period, this phenomenon significantly contributes to the sediments production and consequently the landscape evolution of steep basins (STOCK \& DIETRICH, 2003). Therefore, from a technical point of view (disaster management, soil and water conservation, etc.) and from a scientific point of view (hydrology, geomorphology, and hydrogeomorphology), it is strongly required to increase the number of studies and publications related to debris flows in order to popularize and educate this phenomenon in the community.

\subsection{Acknowledgements}

The authors thank the members of the Research Group on Natural Disasters (GPDEN) of the Institute of Hydraulic Research (IPH) of the Federal University of Rio Grande do Sul (UFRGS) for daily discussion of debris flow and also Brazilian National Council of Research (CNPq) for providing scholarships.

\section{References}

ALEXANDER, D. Urban landslides. Progress in Physical Geography, v.13, p.157-191, 1989.

ARMANINI, A.; MICHIUE, M. (Eds.) Recent Developments on Debris Flows. Berlin: Springer-Verlag, 1997. $226 \mathrm{p}$.

BELOW, R.; WIRTZ, A.; GUHA-SAPIR, D. Disaster Category - Classification and peril Terminology for Operational Purposes. Brussels: CRED / Munich: MunichRe Foundation, 2009. 19p.

BENDA, L.; MILLER, D.; BIGELOW, P.; ANDRAS, K. Effects of postwildfire erosion on channel environments, Boise River, Idaho. Forest Ecology and Management, v.178, p.105-119, 2003.

BRASIL Lei no. 9433, de 08 de janeiro de 1997. Institui a Política Nacional de Recursos Hídricos, cria o Sistema Nacional de Gerenciamento de Recursos Hídricos. Brasília: Brasil, 1997. Disponível em <http://www.aneel.gov.br/cedoc/blei19979433.pdf>. Acesso em 02 de outubro de 2012.

BRASIL Lei no. 12.608, de 10 de abril de 2012. Institui a Política Nacional de Proteção de Defesa Civil. Brasília: Brasil, 2012. Disponível em < http://www.planalto.gov.br/ccivil_03/_Ato2011-2014/2012/ Lei/L12608.htm>. Acesso em 02 de novembro de 2012.

BRUNSDEN, D. Mass movements. In: EMBLETON, C.; THORNES, J. (eds.) Process in geomorphology, London: Edward Arnold, 1979. p.130-86.

COROMINAS, J. The angle of reach as a mobility index for small and large landslides. Canadian Geotechnical Journal, v.33, n.2, p.260-271, 1996.

COROMINAS, J.; VAN WESTEN, C.; FRATTINI, P.; CASCINI, L.; MALET, J.-P.; FOTOPOULOU, S.; CATANI, F.; VAN DEN EECKHAUT, M.; MAVROULI, O.; AGLIARDI, F.; PITILAKIS, K.; WINTER, M.G.; PASTOR, M.; FERLISI, S.; TOFANI, V.; HERVÁS, J.; SMITH, J.T. Recommendations for the quantitative analysis of landslide risk. Bull Eng. Geol. Environ., v.73, p.209-263, 2014. 
CORRÊA FILHO, V. P. José de Anchieta. Revista Brasileira de Geografia, v.XVI, n.2, p.229-233, 1954.

COSTA, J.E. Rheologic, geomorphic, and sedimentologic differentiation of water floods, hyperconcentrated flows, and debris flows. In: BAKER, V.R.; KOCHEL, R.C.; PATTON, P.C. (eds.) Flood geomorphology, New York: John-Wiley \& Sons, 1988. p.113-122.

COUSSOT, P.; MEUNIER, M. Recognition, classification and mechanical description of debris Flows. EarthScience Reviews, v.40, p.209-227, 1996.

CRUDEN, D.M.; VARNES, D.J. Landslide types and processes. In: TURNER, A.K.; SCHUSTER, R.L. (eds.) Landslides investigation and mitigation, Washington: Transportation research board, US National Research Council, 1996. p.36-75. (Special Report 247).

DAVIES, T.R.; PHILLIPS, C.J.; PEARCE, A.J.; ZHANG, X.B. Debris flow behaviour - an integrated overview. IAHS Publ., v.209, p.217-225, 1992.

GABET, E.J.; DUNNE, T. A stochastic sediment supply model for a steep Mediterranean landscape. Water Resources Research, v.39, n.9, p.1237, 2003. doi: 10.1029/2003WRR002341.

GOERL, R.F.; KOBIYAMA, M.; SANTOS, I. Hidrogeomorfologia: Princípios, Conceitos, Processos e Aplicações. Revista Brasileira de Geomorfologia, v.13, n.2, p.103-111. 2012.

GUHA-SAPIR, D.; VAS, F; BELOW, R.; PONSERRE, S. Annual Disaster Statistical Review 2011: The numbers and trends. Brussels: CRED, 2012.42p.

HIGHLAND, L.M.; BOBROWSKY, P. The landslide handbook - A guide to understanding landslides. Reston: U.S. Geological Survey, 2008. 129p. (Circular 1325).

HUNGR, O.; EVANS, S.G.; BOVIS, M.;HUTCHINGSON, J.N. Review of the classification of landslides of the flow type. Environmental and Engineering Geoscience, v.7, p.221-238. 2001.

HUNGR, O.; LEROUEIL, S.; PICARELLI, L. The Varnes classification of landslide types, an update. Landslides, v.11, p.167-194, 2014.

HUTTER, K.; SVENDSEN, B.; RICKENMANN, D. Debris flow modeling: A review. Continuum Mechanics and Thermodynamics, v.8, p.1-35, 1996.

IMAIZUMI, F.; SIDLE, R.; KAMEI, R. 0 Effects of forest harvesting on the occurrence of landslides and debris flows in steep terrain of central Japan. Earth Surface Processes and Landforms, v.33, p.827-840, 2008.

INNES, J.L. Debris flow. Progress in Physical Geography, v.7, p.469-501, 1983.

IRDR - Integrated Research on Disaster Risk. Peril Classification and Hazard Glossary. Beijing: Integrated Research on Disaster Risk, 2014. 24p. (IRDR DATA Publication No. 1).

IVERSON, R.M. The physics of debris flows. Reviews of Geophysics, v.35, p.245-296, 1997.

IVERSON, R.M. Debris flow. In: GOUDIE, A.S. (ed.), Encyclopedia of Geomorphology, London: Routledge, 2004. p.225.

IVERSON, R.M.; REID, M.E.; LAHUSEN, R.G. Debris-flow mobilization from landslides. Annu. Rev. Earth Planet. Sci. v.25, p.85-138, 1997.

JACOB, M.; HUNGR, O. (eds.) Debris-flow hazards and related phenomena. Berlin: Springer-Verlag, 2005. 739p. 
JAN, C.D.; SHEN, H.W. Review Dynamic Modeling of Debris Flows. In: ARMANINI, A.; MICHIUE, M. (eds.) Recent Developments on Debris Flows. Berlin: Springer-Verlag, 1997. p.93-116.

KOBASHI, S.; SUZUKI, M. The critical rainfall (danger index) for disasters caused by debris flows and slope failures. IAHS Publ. v.165, p.201-211, 1987.

KOBIYAMA, M.; MICHEL, G.P. Bibliografia dos trabalhos de fluxos de detritos ocorridos no Brasil no período de 1949-2014: Atualização. Porto Alegre: GPDEN/IPH/UFRGS, 2015. 16p. (Trabalho Técnico GPDEN. No. 02).

KOBIYAMA, M.; CHAFFE, P.L.B.; GOERL, R.F.; GIGLIO, J.N.; REGINATTO, G.M.P. Hydrological disasters reduction: lessons from hydrology. In: SENS, M.L.; MONDARDO, R.I. (eds.) Science and Technology for Environmental Studies: Experiences from Brazil, Portugal and Germany, Florianópolis: Federal University of Santa Catarina, 2010a. p.49-72.

KOBIYAMA, M.; GOERL, R.F.; CORREA, G.P.; MICHEL, G.P. Debris flow occurrences in Rio dos Cedros, Southern Brazil: meteorological and geomorphic aspects. In: WRACHIEN, D.; BREBBIA, C.A. (eds.) Monitoring, Simulation, Prevention and Remediation of Dense Debris Flows III, Southampton: WITpress, 2010b. p.77-88.

LANCASTER, S.T.; HAYES, S.K.; GRANT, G.E. Effects of wood on debris flow runout in small mountain watersheds. Water Resources Research, v.39, n.6, 2003. doi:10.1029/2001WR001227.

MARCELINO, E. V. Mapeamento de áreas susceptíveis a escorregamentos no município de Caraguatatuba (SP) usando técnicas de sensoriamento remoto e SIG. São José dos Campos: INPE, 2003. 228p. (Dissertação de Mestrado em Sensoriamento Remoto).

MARCELINO, E.V.; NUNES, L.H.; KOBIYAMA, M. Banco de dados de desastres naturais: análise de dados globais e regionais. Caminhos de Geografia, v.6, n.19, p.130-149, 2006.

MAZZORANA, B.; HÜBL, J.; ZISCHG, A.; LARGIADER, A. Modelling woody material transport and deposition in alpine rivers. Natural Hazards, v.56, p.425-449, 2011.

MICHEL, G.P.; GOERL,R.F; KOBIYAMA, M. Critical rainfall to trigger landslides in Cunha River basin, southern Brazil. Natural Hazards, v.75, p.2369-2384, 2015. DOI 10.1007/s11069-014-1435-6.

MINISTÉRIO DA INEGRAÇÃO NACIONAL Instrução normativa No. 01, de 24 de agosto de 2012. Brasília: Brasil, 2012. Diário Oficial da União 169 e 170.

OKUDA, S.; SUWA, H.; OKUNISHI, K.; NAKANO, K.; YOKOYAMA, K. Synthetic observation on debris flow. Part 3. Observation at valley Kamikamihorizawa of Mt. Yakedake in 1976. Annuals DPRI v.20B-1, p.237-263, 1977.

PETLEY, D.N. Landslides and engineered slopes: protecting society through improved understanding. In: EBERHARDT, E.; FROESE, C.; TURNER, A.K.; LEROUEIL, S. (eds.) Landslides and engineered slopes, London: CRC Press, 2012. p.3-13.

RICKENMANN, D. Empirical relationships for debris flows. Natural Hazards, v.19, n.1, p.47-77, 1999.

RICKENMANN, D. Runout Prediction Methods. In: JACOB, M.; HUNGR, O. (eds.) Debris-flow hazards and related phenomena, Berlin: Springer-Verlag, 2005. p.305-324.

ROSA FILHO, A.; CORTEZ, A.T.C. Os deslizamentos de encostas nas favelas em áreas de risco da "suíça brasileira": Campos do Jordão (SP). In: 1 SIMPGEO/SP, Rio Claro, Anais, 2008. p.587-595.

SCHEUREN, J-M.; WAROUX, O.P; BELOW, R.; GUHA-SAPIR, D. Annual Disaster Statistical Review: the Numbers and Trends 2007. Brussels: CRED / Munich: MunichRe Foundation, 2008. 47p. 
SCHLUMBERGER. Über den Muhrgangam 13 August 1876 im Wildbache von Fauconbei Barcelonnte (Niederalpen). In: DEMONZY, P. (org.) Studienüber die Arbeiten der Gebirge, 1882. p.289-299.

SEO, J.I.; NAKAMURA, F.; CHUN, K.W. Dynamics of large wood at the watershed scale: a perspective on current research limits and future directions. Landscape Ecological Engineering, v.6, p.271-287, 2010.

SEPÚLVEDA, S.A.; PETLEY, D.N. Regional trends and controlling factors of fatal landslides in Latin America and the Caribbean. Natural Hazards and Earth System Sciences, v.15, p.1821-1833, 2015.

SHRESTHA, B.B.; NAKAGAWA, H.; KAWAIKE, K.; BABA, Y.; ZHANG, H. Driftwood deposition from debris flows at slit-check dams and fans. Natural Hazards, v.61, p.577-602, 2012.

STOCK, J.; DIETRICH, W.E. Valley incision by debris flows: evidence of a topographic signature. Water Resources Research, v.39, n.4, 1089, 2003. doi: 10.1029/2001WR001057.

STOFFEL, M.; WILFORD, D. Hydrogeomorphic processes and vegetation: disturbance, process histories, dependencies and interactions. Earth Surface Processes and Landforms, v.37, p.9-22, 2012.

SUZUKI, M.; KOBASHI, S. The critical rainfall for the disasters by slope failures. J. JSCEC, n.121, p.16-26, 1981.

SUZUKI, M.; FUKUSHIMA,Y.; TAKEI, A.; KOBASHI, S. The critical rainfall for the disasters caused by debris movement. J. JSCEC, n.110, p.1-7, 1979.

TAKAHASHI, T. Debris flow. In: ASHIDA, K.; TAKAHASHI, T.; MICHIUE, M. (org.) Sediment disasters in river and their countermeasures. Tokyo: Morikita Shuppan, 1983. p.55-149.

TAKAHASHI, T. Debris flow. Rotterdam: Balkema, 1991. 165p. (Monograph of IAHR).

TAKAHASHI, T. Debris Flow S Mechanics, Prediction and Countermeasures. Leiden: Taylor \& Francis/ Balkema, 2007. 448p.

TAKAHASHI, T. A review of Japanese debris flow research. International Journal of Erosion Control Engineering, v.2, n.1, p.1-14, 2009.

TATIZANA, C.; OGURA, A.T.; CERRI, L.E.S.; ROCHA, M.C.M. Análise de correlação entre chuvas e escorregamentos na Serra do Mar, município de Cubatão. In: V Congresso Brasileiro de Geologia de Engenharia, São Paulo, Anais, v.2, 1987. p.225-236.

TOMINAGA, L.K.; SANTORO, J.; AMARAL, R. (orgs.) Desastres naturais: conhecer para prevenir. São Paulo: Instituto Geológico, 2009. 196p.

UNDP Reducing disaster risk: a challenge for development. New York: UNDP, 2004.130p.

USGS Debris Flow Hazards in United States. Denver: USGS National Landslide Information Center, 1997. 4p. Acesso em http://pubs.usgs.gov/fs/fs-176-97/fs-176-97.pdf em 10/10/2014.

VANDINE, D.F.; BOVIS, M. History and Goals of Canadian Debris Flow Research, A Review. Natural Hazards, v.26, p.69-82, 2002.

VARNES, D.J. Slope movement types and processes. In: SCHUSTER, R.L.; KRIZEK, R.J. (eds.) Landslides, analysis and control. Washington: Transportation research board/National Academy of Sciences, 1978. p. 11-33. (Special report 176).

VENDRUSCOLO, S.; KOBIYAMA, M. Interfaces entre a Política Nacional de Recursos Hídricos e a Política Nacional de Defesa Civil, com relação aos desastres hidrológicos, no Brasil. In: Jornadas Internacionales sobre Gestión Del Riesgo de Inundaciones y Deslizamientos de Laderas. São Carlos: USP/EESC/NIBH, Anais, 2007. 22p. 
WALLERSTEIN, N. P. Dynamic model for constriction scour caused by large woody debris. Earth Surface Processes and Landforms, v.28, p.49-68, 2003.

WIECZOREK, G.F.; GLADE, T. Climatic factors influencing occurrence of debris flows. In: JACOB, M.; HUNGR, $O$ (eds.) Debris-flow hazards and related phenomena. Berlin: Springer-Verlag, 2005. p.325-362.

WILFORD, D.J.; SAKALS,M.E.; INNES, J.L.; SIDLE, R.C.; BERGERUD, W.A. Recognition of debris flow, debris flood and flood hazard through watershed morphometrics. Landslides, v.1, p.61-66, 2004.

ZNAMENSKY, D. Debris and mudflow initiation processes in Brazilian tropical and subtrocpical humid and mountainous environments. In: LACERDA, W.A.; PALMEIRA, E.M.; COELHO NETTO, A.L.; EHRLICH, M. (eds.) Extreme rainfall induced landslides: an international perspective, São Paulo: Oficina de Textos, 2014. p.103-127. 